\title{
Avatar: A Marxist Saga on the Far Distant Planet
}

\author{
Yong Tang \\ Y-Tang@wiu.edu, Department of English and Journalism, Western Illinois University, USA
}

\begin{abstract}
This article presents a critical and cultural study on Avatar, the Hollywood science fiction blockbuster. After using classical and current Marxist theories to examine James Cameron's major films and using textual analysis to explore Chinese bloggers' comments on the film Avatar, the paper argues that, like Cameron's other major films, Avatar is a cinematographic manifesto of Marxism. The class struggle between capitalists and proletarians is evident throughout the movie's whole narrative structure. Cameron is not neutral in his approach to cinematic worldview. Like in his previous films, also this time Cameron expresses solidarity with poor people and struggles against the rich. The confrontational nature of the worldview embedded in the movie has been used by audiences in China, Brazil, Palestine and elsewhere as a weapon to fight against social oppression.
\end{abstract}

Keywords: Avatar, Marxism, capitalism, neoliberal capitalism, imperialism, primitive accumulation, accumulation by dispossession, James Cameron, Hollywood, worldview, China, forced eviction, bloggers, social oppression

Acknowledgement: This article owes a lot to inspirations from Dr. Matt McAllister, Professor and Assistant Graduate Program Chair at The Pennsylvania State University College of Communications. The paper was initially written for a graduate course (one of my favorite courses at Penn State!) taught by Dr. Matt McAllister. I was happy that Dr. McAllister was present when I presented this paper at the 2011 International Communication Association (ICA) annual conference in Boston. This project would not be possible without Dr. Matt McAllister's continued support and encouragement. I am also deeply grateful to two anonymous reviewers for helpful suggestions and detailed comments on earlier drafts. Finally, I would like to thank the Western Illinois University Writing Center consultants for their help during the revision process.

Since its release in December 2009, Avatar, the 3-D Hollywood blockbuster, has gained unexpected political significance in different areas of the world. In January 2010, Avatar was pulled from every 2-D movie screen in the People's Republic of China, despite its unprecedented popularity in the country (Bates, 2010; LaFraniere, 2010; Tran, 2010). Speculation was that the Chinese government's decision to ban Avatar was based on the film's political sensitivity. Many Chinese moviegoers drew a parallel between the sufferings of the indigenous people in Avatar and their own. Much like what the invaders from Earth did to the residents of the fictitious Pandora, some Chinese local government officials and greedy real estate developers violently evict farmers and city dwellers from their homes, demolish their buildings, and redevelop their land. Officials and businessmen do so purely to satisfy their appetite for huge profit.

In February 2010, in the West Bank of the Jordan River, some Palestinian activists dressed up like the oppressed aliens from Avatar to protest against the Israeli occupation. The demonstration was inspired by Liana Badr, a Palestinian author and documentary filmmaker in Europe. Badr was "so moved by the film's similarity to the Palestinian experience" in the West Bank that she recommended the science fiction movie to her Palestinian friend, a leading organizer of this protest (Franzen, 2010, para. 3).

In April 2010, indigenous leaders in the Amazon rainforest wrote letters to the Avatar director James Cameron, asking him to help in their battle to stop the building of a dam proposed by the Brazilian government (Duke, 2010). Once the construction is complete, the dam would become one of the largest hydroelectric projects in the world. Tribal leaders believe that a project of this magnitude would displace indigenous people, devastate a large amount of rainforest and damage their indigenous culture, just like what the greedy humans did to the Navi in Avatar.

Why has Avatar, an apparent Hollywood commercial science fiction movie, stirred so much political sentiment among so many foreign audiences, especially among those oppressed and underprivileged? What common theme runs through major movies directed by Cameron? Why did Avatar 
provoke such a huge controversy in China? What is behind Cameron's decision to embrace a certain worldview while rebuking others? How can a movie embedded with unpopular worldviews be so popular? The purpose of this paper is to provide some tentative answers to these research questions.

This paper's aim is to conduct a critical and cultural study on the science fiction blockbuster Avatar. Traditional Marxism and current Marxist theories of imperialism and neoliberalism will be employed to examine Cameron's major movies. A textual analysis of the Chinese blogger's comments on the film Avatar will be done.

The first section of this article will examine all previous major films directed by James Cameron and will explore how these films run through a common theme of Marxist worldview. The second section will analyze the underlying worldview in Avatar and examine differences and similarities between Avatar and other Cameron films. The third section will use China as a specific case to illustrate why and how some Chinese audiences relate the Marxist worldview of Avatar to their real life situations. The fourth section will explore why James Cameron prefers to employ Marxist worldview in his films. In the fifth section of this paper, the author attempts to explain why films directed by Cameron can be so financially successful despite the lack of popularity of the Marxist worldview in the United States. The paper concludes that, like most of Cameron's other major films, Avatar is a cinematographic manifesto of Marxism.

\section{The Worldview in Cameron's Pre-Avatar Films}

Throughout his career, James Cameron has directed seven major films: The Terminator (1984), Aliens (1986), The Abyss (1989), Terminator 2: Judgment Day (1991), True Lies (1994), Titanic (1997), and Avatar (2009).

Marxist overtones are found in The Abyss, Aliens, and Titanic. In The Abyss, there is a "firmly intact" class system (James, 1999, p.39). The primary struggle is between the working class, which is represented by the hero Bud Brigman (Ed Harris), and the capitalist-military complex, which is represented by the villain Hiram Coffey (Michael Biehn). Brigman is characterized as a "noble, decent and handsome" person (James, 1999, p.40), while Coffey is characterized as a "stern, thoughtless and harsh" disciplinarian (James, 1999, p.40).

A similar class confrontation is found in Aliens. In this film, the working class representative Ellen Ripley (Sigourney Weaver) is the hero, while Carter Burke (Paul Reiser) is the representative of capitalists. Ripley is described as an "earthy, natural, strong and motherly" woman (James, 1999, p.40), whereas Burke is portrayed as "a perfect embodiment of the evil capitalist" (James, 1999, p.40).

Scholar James (1999) asserted that Titanic is even a much stronger declaration of Marxist worldview than both Aliens and The Abyss. James (1999) stated:

[N]o matter how explicit Cameron made his views on class and power struggles in the Abyss and Aliens, both films serve primarily as an ideological warm-up for Titanic, which makes the Marxist class struggle the dominant paradigm within which the narrative is constructed " ( $p .41$, emphasis added).

According to James (1999), in Titanic, the ship itself is an embodiment of class struggle. The lower and upper classes are physically isolated from each other. Within the film, the lower class can never reach the same level that the upper class can.

James (1999) declared that Titanic highlights a seemingly impossible love story between two young people from the bourgeoisie and the proletariat. The proletariat is embodied by Jack Dawson (Leonardo DiCaprio), while the bourgeoisie is represented by Rose DeWitt Bukater (Kate Winslet). The love story is made possible only because Rose betrays her class, and Jack is so "immediately likeable" (p.42), while his wealthy competitor Cal Hockley (Billy Zane) is so "immediately dislikable" (p.42).

Cameron's Terminator (1984) and Terminator 2: Judgment Day (1991) are also expressions of a Marxist worldview. Cameron's Terminator films share "intriguing similarities" with the predictions 
and analysis of Karl Marx (Ewing, 2009, p.93). The two Terminator films indicate that the development of technology in a capitalistic society is naturally harmful and dangerous, thus "judgment day" for capitalism is both unavoidable and inevitable. However, according to statements from the movie Terminator, technology can be reclaimed to make human beings freer (Ewing, 2009). These standpoints about the role of technology in a society are exactly what Marx argued.

Marx identified a couple of detrimental effects of technology in capitalist societies. For example, according to Marx (1976), because machinery makes muscular power less important, capitalists tend to employ women and children, "[t]he labor of women and children was therefore the first result of the capitalist application of machinery (p.517)!" Machinery is also "the most powerful means of lengthening the working day (p.526)" and makes intensification of labor possible (p.533). However, Marx is neither a pessimist nor an optimist in technology. Instead he holds a dialectical view of technology, seeing machinery as having "contradictory potentials and that under capitalism the negatives predominate" (Fuchs, 2011, p.114). In the same vein with the Terminator theme, Marx (1976) stated:

[M]achinery in itself shortens the hours of labour, but when employed by capital it lengthens them; since in itself it lightens labour, but when employed by capital it heightens its intensity; since in itself it is a victory of man over the forces of nature but in the hands of capital it makes man the slave of those forces; since in itself it increases the wealth of the producers, but in the hands of capital it makes them into paupers (pp.568-569).

\section{Avatar: Class Struggle beyond National Borders}

Avatar takes place in the year 2154 on Pandora, a fictitious moon of a far distant planet. On Pandora lives an indigenous people called the Na'vi. The Na'vi inhabitants live peacefully with nature and worship Eywa, a mother goddess. The RDA Corporation from Earth wants to mine a precious mineral on Pandora and appoints Parker Selfridge (Giovanni Ribisi) as head of the operation and Colonel Miles Quaritch (Stephen Lang) as head of private security forces.

Selfridge and Quaritch send the handicapped Marine Jake Sully (Sam Worthington) to infiltrate the Na'vi with the use of an "Avatar" identity. During the encounter with Neytiri (Zoe Saldana), the Na'vi chief's daughter, Jake realizes that the Na'vi way of life is in harmony with the world around them and he finally falls in love with Neytiri. When security forces of the RDA Corporation come to evict the Na'vi from their homeland, Jake betrays his mission. He does not fight for the RDA Corporation any more. Instead he leads the Na'vi to defend their home and their way of life in a war against the greedy humans.

Striking similarities exist between Avatar and Cameron's other films (with True Lies most likely being the only exception) in terms of an ideological and worldview tilt. Like previous Cameron films, Avatar continues to be a cinematographic description of the power struggle between the working class and the capitalists. The working class in Avatar is represented by Neytiri and her aboriginal Na'vi people on Pandora. The imperialists/capitalists are characterized by Selfridge and Quaritch, the two bad guys who lead the industrial-military complex from Earth.

Like most of Cameron's previous films, Avatar features a protagonist (Jake) who betrays the capitalist system and joins the working class, just like what the female protagonist did in Titanic. In Avatar, people representing capitalist interests (Selfridge and Quaritch) are cast in an extremely negative light. They are greedy, ruthless and have no compassion. By contrast, as the exploited underclass, the Na'vi residents are praised and even romanticized. The Na'vi people may not be rich by the standards of the capitalists, but they understand and appreciate the value and beauty of the environment. They live in a perfect harmony with the world around them, which is lacking on Earth. In the same vein, Jake is portrayed as warm-hearted, brave, compassionate and intelligent because he betrays his capitalist background. Such characterizations of protagonists and antagonists indicate that Cameron is standing with the working class.

However, noticeable differences between Avatar and Cameron's other films in terms of their underlying worldview are worth exploring. First, unlike Cameron's previous films, Avatar explicitly 
critiques U.S. foreign policy when it describes the RDA's military attack against the Na'vi as one of "shock and awe" in which they will fight "terror with terror". The invasion of Iraq in 2003 was also known as a campaign of "shock and awe" ("Shock and Awe," 2003). The similarity of wording indicates an implicit condemnation of the United State's occupation of Iraq and the U.S. global war against terror.

Second, unlike Cameron's previous films, Avatar features a classic class struggle beyond national borders. Like Marx and Lenin, the movie critiques colonialism and imperialism. As Marx (1976) has noted, colonialism is another form of capitalism, capitalists used colonization as a means to achieve primitive accumulation, the "original sin" of capital (p.873). Lenin (1917) observed that imperialism is the highest stage of capitalism. Lenin's critique of capitalism still remains relevant today (Fuchs, 2010). Avatar is also a critique of contemporary neoliberal imperialism as an ongoing primitive accumulation that is based on accumulation by dispossession (David, 2003; Fuchs, 2011; Fuchs, 2010).

Film critic Clover (2010) pointed out that Avatar contains an anti-imperialist overtone. Another movie commentator Davidson (2010) suggested that Avatar is "countercultural" (p. 14) and reflects a modern age "environmentalist" worldview (p. 14). In fact, Avatar has been applauded by a number of leftists around the world. For example, American socialist Nagesh Rao (2010) contended that what "really stands out" in Avatar is its ruthless critique of corporate greed and its "inspiring tale of solidarity and resistance" against occupation (p. 1). Rao (2010) claimed that Avatar "reenacts" the genocide of indigenous populations by "colonial capitalism" (p. 1).

What hypothetically happens in the movie Avatar is actually unfolding in the tropical forests and mountains of Central and South America, according to another social commentator, Carlos A. Quiroz. Quiroz (2010) wrote that corporations on Earth are trying to take over the indigenous peoples' ancestral lands "in complicity with the local puppet governments" (para.3).

It is really an interesting irony that a big-budget blockbuster like Avatar relentlessly attacks the capitalist system, but without such a system, the film could never build its success at such a massive level.

\section{A Case Study: Avatar Repercussions in China}

In terms of overall box-office records, Avatar is the most popular film in Chinese history (Child, 2010). One mountain in China was even renamed as "Avatar Mountain" after the film's flamboyant debut in the country (Le \& Blanchard, 2010). Why did a Hollywood blockbuster become so popular in China? Why was the 2-D version of Avatar banned in this country? ${ }^{1}$

As discussed in the introduction section, one of the major reasons behind the widespread popularity and subsequent ban was that the film pulls at the heartstrings of Chinese moviegoers regarding the hot-button social issue of the forced eviction. There is a large amount of domestic and foreign media coverage about the association of the popularity of Avatar in China with forced eviction (Liu et al., 2010).

Forced eviction, once a common problem during the process of primitive accumulation in precapitalist societies, is becoming a major social issue in China today. Many local governments at various levels, relying on the huge land transferring fees as the major source of revenues, collude with real estate developers to brutally evict city residents and farmers. Houses of poor people are often demolished and their lands are redeveloped. Most of the time compensation is disproportionately low. So far, 30 million citizens have been evicted from their homes during the course of China's three-decade-long construction boom (Liu, 2010). Forced demolitions often lead to violence and at times, even death. In November 2009, a 47-year-old woman in the southwestern city of Chengdu protested the forced demolition of her house by setting herself on fire. She was burnt to death soon after starting the fire (Sun, 2010).

\footnotetext{
${ }^{1}$ Most theatres in China do not have 3-D capabilities.
} 
Forced eviction epitomizes China's painful transition from "socialism with Chinese characteristics" to "capitalism with Chinese characteristics" (Lu, 1999, p. 487). ${ }^{2}$ The Harvard-educated Chinese expert Pei (2006) believed that China today has become a Neo-Leninist state and socialism has turned out to be crony capitalism with Chinese characteristics. After conducting a Marxist analysis of the changes in the communication sector in China, communications scholar Zhao (2008) found that contemporary China has embarked on the road of neoliberalism.

This lengthy process of transition, accelerated by China's entry into the World Trade Organization, has benefited Chinese political, bureaucratic and economic elites at the expense of tens of thousands of workers and farmers. During Mao's era, workers and farmers were the bulk of Chinese citizens and they were relatively privileged. Today, such ordinary citizens are becoming increasingly marginalized. By contrast, many party officials and private businessmen are becoming new capitalists (Blecher, 2002). In 2004, nearly half of the individuals on Forbes' list of the 100 richest people in China were real estate developers. At the same time, many party officials became rich instantly (Pei, 2006). Social unrest in China has grown steadily as a result of China's transition to a market economy as well as the increased integration with global capitalism (Robert \& Zhao, 2009). Land disputes are becoming a focal point of the current class struggle.

Avatar provided an ideal opportunity for those oppressed in China to voice their concerns and express their sufferings as homeless people. Chinese citizens found a striking similarity between the plot of Avatar and all kinds of forced evictions occurring on a regular basis in China. With a textual analysis on Chinasmack.com, ${ }^{3}$ results show that the majority of online discussions by Chinese netizens on Avatar and forced eviction ran through a common theme: the struggle between the powerful and the powerless, the rich (officials and real estate developers) and the poor (farmers and workers), the haves and the have-nots.

According to Chinasmack.com, many netizens left sarcastic postings on numerous online forums. For instance, one netizen commented that "China's demolition crews must go sue [Director James] Cameron [for] copyright infringement" (Liu, 2010, para. 3). Another netizen joked that "I am wondering whether Cameron had secretly lived in China before coming up with such a brilliant idea of writing the story of 'Avatar' (Sun, 2010, para.12)." On top of a house in Beijing, the evicted house owner hung a red banner high with Chinese characters that read, "Inspirations from Avatar. Fight to the Death in Defending Homeland (Gen, 2010, para. 3)!" The picture showing the banner soon circulated widely on the Internet.

Among those online postings, classical Marxist quotations were not uncommon. Bloggers frequently used such quotations to indirectly express their anger. ${ }^{4}$ Among those quotations were "where there is forced eviction, there is resistance" (Zhen, 2010); "Capital comes dripping from head to toe, from every pore, with blood and dirt (Marx, 1976, p. 926)." The latter is a direct reference to the brutal process of primitive accumulation described by Marx. Some netizens made a parallel between forced eviction in China and the Enclosure Movement in Britain between 1760 and 1832. They resorted to insinuation by posting "sheep eat men! [羊吃人!]" to tactfully compare the

\footnotetext{
${ }^{2}$ Scholar Lu argued that the Communist Party slogan "building socialism with Chinese characteristics" sends out the message that it is acceptable to pursue capitalism.

${ }^{3}$ Chinasmack.com is a blog site created by a Chinese girl in Shanghai. Currently it is one of the most influential blogs covering China. This site scans the ever growing world of Chinese netizens for newsworthy items, then translates them into readable English. Chinasmack.com was chosen for this study because a) Chinese authorities censor the domestic cyberspace on a daily basis. Most online materials concerning the Avatar episode were deleted on the grounds of being too politically sensitive, controversial or immoral; b) Internet censors don't pay too much attention to foreign-language materials; c) Chinasmack.com features a large archive of Chinese netizens' discussions on Avatar and forced eviction.

${ }^{4}$ Internet censors in China would not delete those classical Marxist quotations because such remarks are one hundred percent correct in the Chinese mainstream ideological context. Bloggers would not be punished for posting such Marxist quotations because such quotations conform with the socialist ideology.

${ }^{5}$ This quotation came from "where there is oppression, there is resistance". It is a phrase commonly attributed to late Chairman Mao Zedong. However, Chinese sources suggest that this phrase is not in Mao's writings at all. Mao used this phrase in his interview with American journalist Edgar Snow in 1965. This phrase was used verbatim in 1972 in the Joint Communique of the United States of America and the People's Republic of China (Shanghai Communique).
} 
sufferings of today's Chinese farmers and workers with those of English peasants dispossessed by brutal enclosures (More, 1999, p. 101). ${ }^{6}$

The use of "Sheep eat men" by Chinese bloggers shows that Avatar was read by some as a criticism of contemporary neoliberal capitalism/new imperialism that is based on the principle of accumulation by dispossession. According to Karl Marx, primitive accumulation was the process by which capitalists used force to evict residents from their lands and then privatized those lands. Two classes thus came into being: private owners and free laborers (Marx, 1976, p. 873). According to scholar Harvey (2003), primitive accumulation is not gone and it still exists today on a global scale. He proclaimed that "[a]ll the futures of primitive accumulation that Marx mentions have remained powerfully present within capitalism's historical geography up until now" (p. 145). Harvey (2003) declared that today's primitive accumulation could be termed as "accumulation by dispossession" (p. 137). Harvey (2003) argued that accumulation by dispossession takes many forms such as financialization, privatization, deregulation, imperialist warfare and many others (pp. 137-182).

Forced eviction in China today explains vividly how accumulation by dispossession is happening in this giant country. Ironically, communist leaders just threw capitalism into the dustbin more than half a decade ago when they took charge of the country.

\section{Why is Marxism the Worldview Underpinning Avatar?}

As discussed in previous sections, Cameron is fond of using the Marist worldview as a construct within his movies. However, Marxism is not a popular worldview in the movie industry. This assertion is validated by the general lack of hostility toward capitalism in American mainstream movies since the first half of the 20th century (James, 1999, pp. 36-44). Instead, hostility toward communism in the film industry is conspicuous, though the degree of such hostility varies at different periods of time.

The U.S. movie industry's enchantment with capitalism and its aversion to communism are not without reason. One explanation is that anti-radicalism has a strong tradition in America. It first emerged in the late 1790s, when the Federalist majority in Congress passed the Alien and Sedition Acts, targeting European immigrants who were sympathetic with French revolutionary ideas (Ceplair, 2008). When the Soviet Union was founded in 1922, anti-communism became a new form of anti-radicalism in the United States. Since that time, America had seen the peak of anticommunism in the First Red Scare (1919-1920) and the Second Red Scare (1947-1957). In the 1950s, the U.S. government blacklisted many Hollywood writers, actors, and directors as communists or pro-communists (Ceplair, 2008). Since the collapse of the Soviet Union and its Eastern bloc communist regimes, anti-communism in the United States has dwindled to its lowest level. However, it is still embedded in the political psyche of American people. Hollywood is no exception. Although the Studio Era ended and the censorship of the Production Code was replaced by the more flexible ratings system of the Motion Picture Association of America (MPAA), "there is still a great deal of cultural control exerted over movies" (James, 1999, p. 38).

Another possibility is that the cultural industry in this country has been used by some capitalists for the purpose of deceiving or misleading the general public. According to the Frankfurt School philosophy, the cultural industry in nature is an industry of mass deception (Adorno \& Horkheimer, 2007). One of the industry's major goals is to support the cultural status quo and to keep the capitalist economic system in motion (Adorno \& Horkheimer, 2007). In this sense, it is inspiring to recall what film scholar Eisenstein (1957) rightly contended: "American capitalism finds its sharpest and most expressive reflection in the American cinema" (p. 196).

Why does Cameron embrace Marxism despite the unpopularity of this worldview? Clues may be found from his family upbringing and his less glamorous early years. According to The Futurist, an

\footnotetext{
${ }^{6}$ "Sheep eat men" originated from author and social philosopher Thomas More, who criticized the cruelty of the British primitive accumulation in his book Utopia. The original sentence was "Your sheep, that were wont to be so meek and tame and so small eaters, now, as I hear say, be become so great devourers, and so wild, that they eat up and swallow down the very men themselves."
} 
autobiography of Cameron, the award-winning director was born in Canada and grew up in a small town (Keegan, 2009; Goodyear, 2009). His father was an engineer at a paper company and his mother raised five children. Cameron was the oldest and the ringleader of his siblings. When Cameron was 17 , he moved to a small city in California with his family, leaving Canada without a highschool diploma. He started taking classes at a small community college in California and then dropped out. When he was in his early 20 s, Cameron worked as a truck driver, a precision tooland-die machinist, janitor and a gas-station attendant. His girlfriend at the time worked at Bob's Big Boy Diner. In addition, Cameron is an atheist. When the other kids read the Lord's Prayer in school, Cameron decided not to follow suit because he considered Christian prayer as a tribal chant (Keegan, 2009; Goodyear, 2009).

Given the descriptions of Cameron's early life in The Futurist, it is clear that Cameron came from a very humble beginning. Concluding that Cameron is a Marxist is definitely premature. However, it is safe to infer that Cameron has a strong working-class mentality that developed from his humble family background and his early struggling years.

It is thus not difficult to understand why Cameron once declared to a reporter in a strikingly frank manner "[g]reat wealth makes me uncomfortable" (Brown \& Ansen, 1997, para. 6) and added that "[g]reat poverty would also make me uncomfortable" (Brown \& Ansen, 1997, para. 6). Cameron once stated in a New Yorker interview:

I try to live with honor, even if it costs me millions of dollars and takes a long time.... It's very unusual in Hollywood. Few people are trustworthy-a handshake means nothing to them. They feel they're required to keep an agreement with you only if you're successful, or they need you. l've tried not to get sucked into the Hollywood hierarchy system. Personally, I don't like it when people are deferential to me because I'm an established filmmaker. It's a blue-collar sensibility (Goodyear, 2009, para. 7).

Living with honor is much easier said than done. But for Cameron, it seems he is trying to live up to his words. It was reported that he finally accepted the invitation to become an environmental activist in the Amazon rainforest region. His goal is to help indigenous people fight against a controversial dam proposed by the Brazilian government (Phillips, 2010; Duke, 2010).

\section{Financial Success and Limitations of the Avatar's Worldview}

Without any doubt, Avatar has become a global phenomenon for breaking so many records. Since its release in December 2009, it has become the most expensive movie in history. According to the New York Times estimate, Avatar's budget ranges from $\$ 230$ million to $\$ 500$ million (Cieply, 2009). Avatar has also become the most profitable movie, earning Cameron and his team more than $\$ 2.7$ billion worldwide (Plambeck, 2010). The success of Avatar even boosted the economic performance of News Corporation, the owner of the movie studio 20th Century Fox, which produced Avatar. News Corporation reported unexpectedly high revenues of $\$ 8.8$ billion in its fiscal third quarter, ending on March 31, 2010 (Plambeck, 2010). When receiving the Oscar award for Titanic, Cameron exclaimed, "I'm king of the world" (Grover et al., 2010)! After Avatar, Cameron is definitely the "king of the world" again in terms of the profitability of his films (Grover et al., 2010).

As discussed earlier, Marxism is not a popular worldview in Hollywood. Why do people still scramble to the theatres to watch a movie with a worldview they don't like? As film critic Clover (2010) stated:

By common account, Avatar asks the great question of contemporary art, the one hip-hop has been asking unfailingly for some time: will we put up with a creepy worldview just because the sensuals are cool (p.6)?

The reasons why Avatar and Cameron's other blockbusters become so financially successful are threefold. First, Cameron is well known for his talent in producing high quality special visual effects. He was once honored with a Visual Effects Society (VES) Lifetime Achievement Award for his work on Avatar (Visual Effects Society, 2010; “James Cameron's Best Special Effects," 2010). Cam- 
eron's visual effects are so breathtaking that his worldview in the movies is often easily ignored by the audiences. As film critic James (1999) rightly put it, "his films are usually so large, loud, bold, and brashly entertaining that whatever ideological content exists in the films' substructures is easily missed by the vast majority of the audiences" (p.39).

Second, the political/worldview narration of Cameron's films exists almost entirely on a secondary level; a level that resides just beneath the primary narrative content. None of his movies have constructed the political/worldview content as the central feature of the filmic texts.

Third, Cameron is good at hiding his worldviews in the movies. Unlike "New" American cinema of the late 1960s and early 1970s as "superficially radical, internally conservative" (Ray, 1985, p. 296), Cameron's movies adopt an opposite strategy of being "superficially conservative, internally radical" (Ray, 1985, p. 296). In doing so, Cameron manages not to estrange his mainstream audiences.

For instance, Cameron tries to please the U.S. mainstream traditional liberal values and stereotypes about race and gender. Take Avatar for an example. In the film, it is Jake, a white male, who leads the Na'vi people to victory. This portrays racism in a subtle manner: the white man is still the center of the narrative and the protagonist through which the events are viewed; the Na'vi people are still exotic, alien, other and noble savages. Just as philosopher and film critic Žižek (2010) stated:

Beneath the idealism and political correctness of Avatar...lie brutal racist undertones....[A]paraplegic outcast from earth is good enough to get the hand of a beautiful local princess, and to help the natives win the decisive battle. The film teaches us that the only choice the aborigines have is to be saved by the human beings or to be destroyed by them (para.1 and 14).

To put it more bluntly, such an approach to racial narration belies the white consumption of nonwhiteness. Of course, Cameron is not worse than other Hollywood mainstream directors in revealing his own racial bias. Similar biases could be easily found in other Hollywood movies like Dancing with Wolves (Vera and Gordon, 2003, p.138) and The Last Samurai (Childs, 2009, pp.71-72). Avatar and these other films are telling the same story: a white man is accepted into a closed society of colored people and eventually becomes its most powerful member, and even its savior.

More importantly, the structure of the Na'vi inhabitants is conservatively patriarchal: Neytiri's father is the chief while his wife is the spiritual leader. Hence Avatar is an expression of Cameron's gender stereotype: men should be political leaders and women are leaders of the spiritual world (Davidson, 2010).

Avatar's limitations in its narrative structure in race and gender would at best disappear if the Na'vi people were saved by themselves without the help of a white man. Those limitations would also fade away if the Na'vi society were constructed on the basis of gender equality. The limitations would be gone if the female protagonist Neytiri was featured more prominently, just like Sarah Connor in the first two Terminator films. However, Cameron did not go so far and he did not want to go so far.

\section{Conclusion}

The major task of this paper was to identify the underlying worldview of the movie Avatar and explain why this worldview attracts so many audiences around the world, including China. After a critical and cultural analysis of Avatar and pre-Avatar movies, this paper finds that, like most of Cameron's other films, a Marxist undercurrent runs through Avatar. The conflict between evil capitalists and good working people present in other Cameron's movies is also present in Avatar. As the story teller, Cameron always stands with the warm-hearted and heroic proletarians in their fight against the evil capitalists.

It is important to note that Marxism is not a dominant worldview in Avatar. It is an undercurrent that might easily be ignored by the general audience. However, Chinese netizens, Palestinian people and Brazilian indigenous communities did not ignore such an undercurrent. They took advan- 
tage of the polysemic nature of the film text. Polysemy is a popular phenomenon when interpreting the meanings of cultural texts. For example, An Inconvenient Truth, Al Gore's documentary, was interpreted by audiences either as political jeremiad, autobiography or as science documentary (Rosteck \& Frentz, 2009). Likewise Do the Right Thing, Spike Lee's film, has been interpreted in radically different and even inconsistent ways (Rowland \& Strain, 1994).

Polysemy is even more prevalent in cross-cultural and international settings, as in the case of Avatar. The global audience recreated the meaning of the Avatar text by putting the hidden philosophy into the spotlight. Although the story of Avatar takes place on a far distant planet in a fictional universe, some foreign audiences on Earth saw this as the story of their own. They were deeply moved by the story in which the good working people fight against evil capitalists and colonists. They used the movie Avatar as a media weapon to fight against social oppression which they are experiencing in real life on a daily basis. The working class's resistance against capitalist hegemony in the form of constructing and deconstructing Avatar should not be ignored. Instead, the voice of the marginalized and disadvantaged deserves to be heard.

\section{References}

Adorno, T. W., \& Horkheimer, M. (2007). The culture industry: Enlightenment as mass deception. In T. W. Adorno, T \& M. Horkheimer, Dialectic of Enlightenment. Stanford, CA: Stanford University Press.

Bates, T. (2010, January 19). Too popular "Avatar" pulled from Chinese cinemas. AOL News. Retrieved from http://www.aolnews.com/2010/01/19/too-popular-Avatar-pulled-from-chinese-cinemas/

Blecher, M. (2002). Hegemony and workers' politics in China. The China Quarterly, 170, 283-303.

Brown, C., \& Ansen, D. (1997, December 15). Rough waters: Titanic - an epic romance -

is the most costly movie of all time: The shoot was torture: Is director James Cameron a megalomaniac, a genius or both? Newsweek. Retrieved from http://www.newsweek.com/id/97686

Ceplair, L. (2008). The film industry's battle against left-wing influences: From the Russian Revolution to the blacklist. Film History, 20(4), 399-411.

Cieply, M. (2009, November 8). A movie's budget pops from the screen. The New York Times. Retrieved from http://www.nytimes.com/2009/11/09/business/media/09Avatar.html

Child, B. (2010, January 19). Avatar smashes Chinese all-time box-office record. Guardian. Retrieved from http://www.guardian.co.uk/film/2010/jan/19/Avatar-smashes-chinese-record

Childs, E. (2009). Fade to black and white: Interracial images in popular culture. Lanham, MD: Rowman \& Littlefield.

Clover, J. (2010). The struggle for space. Film Quarterly, 63(3), 6-7.

Corie, B., \& Ansen, D. (1997, December 14). James Cameron a megalomaniac, a genius or both? Newsweek. Retrieved from http://www.newsweek.com/id/97686

Davidson, R. (2010). Avatar: Evaluating a film in a world of its own. Screen Education 57, 10-17.

Duke, A. (2010, April 20). James Cameron joins real-life "Avatar" battle. CNN. Retrieved from http://www.cnn.com/2010/SHOWBIZ/04/20/james.cameron.rain.forest/index.html

Eisenstein, S. (1957). Film form: Essays in film theory, and the film sense. New York: Meridian Books.

Ewing, J. (2009). James Cameron's Marxist revolution. In W. Irwin, R. Brown, \& K. Decker (Eds.), Terminator and philosophy: I will be back, therefore I am (pp. 93-108). Hoboken, NJ: Wiley.

Franzen, C. (2010, February 12). The making of the west bank's "Avatar" protest. AOL News. Retrieved from http://www.aolnews.com/world/article/palestinians-use-Avatar-to-protest-west-bank-barrier/19356749

Fuchs, C. (2010). Critical globalization studies: An empirical and theoretical analysis of the new imperialism. Science \& Society 74(2), 215-247.

Fuchs, C. (2010). New imperialism: Information and media imperialism? Global Media and Communication 6(1), 33-60.

Fuchs, C.(2011). Foundations of critical media and information studies. New York: Routledge.

Gen, H. (2010, April 21). Evicted residents hung Avatar banner for dignity [网友发帖称 房屋被偷拆 挂阿凡达横幅讨说法]. Xiaoxiang Chenbao[潚泪晨报]. Retrieved from http://news.sina.com.cn/s/p/2010-0202/101319611556.shtml

Goodyear, D. (2009, October 26). Man of extremes: The return of James Cameron. The New Yorker. Retrieved from http://www.newyorker.com/reporting/2009/10/26/091026fa_fact_goodyear

Grover, R., Lowry, T., \& White, M. (2010, January 21). King of the world (again): The inside story of how Avatar's James Cameron became the most powerful commercial force in the movie business: Twice. Businessweek. Retrieved from http://www.businessweek.com/magazine/content/10_05/b4165048396178.htm

Harvey, D. (2003). The new imperialism. Oxford: Oxford University Press. 
James Cameron's best special effects. (2010, March 4). Time. Retrieved from http://www.time.com/time/photogallery/0,29307,1968119_2080858,00.html

James, K. (1999). Marxist overtones in three films by James Cameron. Journal of Popular Film \& Television, 27(3), 36-44.

Keegan, R. (2009). The futurist: The life and films of James Cameron. New York: Crown Archetype.

LaFraniere, S. (2010, January 19). China curtails run of "Avatar" as it fills theaters. The New York Times. Retrieved from http://www.nytimes.com/2010/01/20/world/asia/20china.html

Le, Y., \& Blanchard, B. (2010, January 25). "Avatar" inspires China province to rename mountain. Reuters. Retrieved from http://www.reuters.com/article/idUSTRE6001N920100125

Lenin, V. I. (1917). Imperialism, the highest stage of capitalism. In Henry M. Christman (Ed.), Essential Works of Lenin (pp. 177-270). New York: Dover

Liu, M. (2010, February 4). Confucius says: Ouch, Avatar trumps China's great sage. Newsweek. Retrieved from http://www.newsweek.com/id/233068

Lu, X. (1999). An ideological/ cultural analysis of political slogans in communist China. Discourse Society, 10(4), 487-508.

Marx, K. (1976). Capital: A critique of political economy: Volume I. London, UK: Penguin.

More, T. (1999). Utopia. In D. H. Sacks (Ed.), Utopia. New York: Bedford/St.Martin's.

Pei, M. (2006). China's trapped transition: The limits of developmental autocracy. Cambridge, MA: Harvard University Press.

Pei, M. (2006). The dark side of China's rise. Foreign Policy, 153, 32-40.

Phillips, T. (2010, April 18). Avatar director James Cameron joins Amazon tribe's fight to halt giant dam. Guardian. Retrieved from http://www.guardian.co.uk/world/2010/apr/18/Avatar-james-cameron-brazil-dam

Plambeck, J. (2010, May 4). News Corp. gets a lift from ads and "Avatar". The New York Times. Retrieved from http://www.nytimes.com/2010/05/05/business/media/05news.html

Quiroz, C. (2010, January 24). Avatar is real: Pandora is in Central and South America. Green Left Online. Retrieved from http://www.greenleft.org.au/node/43088

Rao, N. (2010, January 7). Anti-imperialism in 3-D. Socialistworker. Retrieved from http://socialistworker.org/2010/01/07/anti-imperialism-in-3D

Ray, R. (1985). A certain tendency of the Hollywood cinema: 1930-1980. Princeton, NJ: Princeton University Press.

Robert, D., \& Zhao, Y. (2009). Short-circuited: Communication and working class struggle in China. Paper presented at the Annual Meeting of the International Communication Association (ICA).

Rosteck, T., \& Frentz, T. (2009). Myth and multiple readings in environmental rhetoric: The case of An Inconvenient Truth. Quarterly Journal of Speech, 95(1), 1-19.

Rowland, R., \& Strain, R. (1994). Social function, polysemy and narrative-dramatic form: A case study of Do the Right Thing. Communication Quarterly, 42(3), 213-228.

"Shock and Awe" campaign underway in Iraq (2003, March 22). CNN. Retrieved from http://www.cnn.com/2003/fyi/news/03/22/iraq.war/

Sun, Y. (2010, January 15). "Avatar": A eulogy for China's nail houses. Xinhua. Retrieved from http://news.xinhuanet.com/english2010/china/2010-01/15/c_13137265.htm

Tran, T. (2010, January 19). China to pull 2D version of "Avatar". CBS News. Retrieved from http://www.cbsnews.com/stories/2010/01/19/tech/main6116253.shtml

Vera, H., \& Gordon, A. (2003). Screen saviors: Hollywood fictions of whiteness. Oxford, UK: Rowman \& Littlefield.

Visual Effects Society (2010, February 28). 8th annual VES awards winners. Visual Effects Society. Retrieved from http://www.visualeffectssociety.com/group/ves-member/8th-annual-ves-awards-winners

Zhao, Y. (2008). Communication in China: Political economy, power, and conflict. Lanham, MD: Rowman \& Littlefield.

Zhen, H. (2010). Where there is forced eviction, there is resistance. The Global Times. Retrieved from http://blog.huanqiu.com/?uid-51876-action-viewspace-itemid-509312

Zhou, R. (2010, January 8). The fourth dimension. China Daily. Retrieved from http://www.chinadaily.com.cn/opinion/2010-01/08/content_9284501.htm

Žižek, S. (2010, March 4). Return of the natives. New Statesman. Retrieved from http://www.newstatesman.com/film/2010/03/avatar-reality-love-couple-sex

\section{About the Author}

Yong Tang

Assistant Professor of Journalism and Mass Media Law at Western Illinois University. He teaches mass media law, news reporting and writing, and other journalism-related courses. His major research interests are mass media law, international journalism, and global media studies. He is a former Washington-based correspondent of the People's Daily, the largest and most politically influential newspaper in the People's Republic of China. He is a doctoral candidate in Mass Communications at The Pennsylvania State University College of Communications. He holds a doctoral degree in international journalism 
from Communication University of China and a master's degree in international policy and practice from The George Washington University. 